brarians, by its books on real estate and business.

The reader has ample material here upon which to reflect on the need for a scholarly and farsighted acquisitiveness in librarians, coupled with solid and sensible accomplishments in administration. The Boston Public Library has fortunately had some librarians distinguished for both: the names of Charles Coffin Jewett, Justin Winsor, and Herbert Putnam are writ large in library history. Trustees and librarians alike may profit from the story told in detail of the construction, without regard to function, of the great architectural monument that is the present library in Copley Square, and the more significant story of attempts to rebuild the interior into the useful and complicated service areas demanded in a modern public library. Anyone who has watched the ingenious changes taking place under the present capable director, Milton E. Lord, will better appreciate the extraordinary complexity of the problems created by the necessity of defrosting architectural icebergs. Branch libraries, bookmobiles, the dual emphasis upon research facilities and services to the reading needs of the general public have their proper parts, as has, too, quite fortunately, the dispute over Macmonnies' sculpture "Bachante." If the reader does not turn from the few pages about the "Naked Drunken Woman" in this book to the author's longer account in the New England Quarterly for December, 1954, he will have missed one of the best stories in library history.

In a note Mr. Whitehill commends David McCord's centennial pamphlet as "full of information and free from the pompous solemnity that affects many commemorative publications of institutions." One can do no better than use the same words to describe Mr. Whitehill's own book. To this should be added a tribute to Rudolph Ruzicka, whose fine illustrations and expertness in book design give the volume a deserved distinction. -Robert E. Moody, Boston University Libraries.

\section{Medical Library Practice}

Handbook of Medical Library Practice, with a Bibliography of the Reference Works and Histories in Medicine and the
Allied Sciences. 2d ed., rev. and enl. Janet Doe, Mary Louise Marshall, editors. Chicago: American Library Association, 1956. 601 p. $\$ 10$.

When the first edition of this Handbook appeared in 1943 it was described as "a manual of procedure and a reservoir of useful data." Emphasis was placed on the latter aspect, with happy results; and happily this revised and enlarged second edition has continued this emphasis. A very wide range of information is included: organization charts; salary scales; factors for calculation of stack capacities; names and addresses of book and periodical dealers; directions for using mending glues; samples of various classification schemes now prevalent; lists of subject heading aids; manufacturers of map cases, display equipment, and microfilm reading machines; checklists for a public relations program; and data on medical library resources, medical library education, and the Medical Library Association. There is something here for everyone. All of it will be of daily usefulness to the younger librarian, and to the librarian of the "oneman" library, while even the most sophisticated and experienced librarian must find in it an invaluable source of occasional help.

The last half of the book deals with reference and bibliographic service applicable to clinical medicine and medical research, and to a discussion of rare books and the history of medicine, both sections being capped with a really magnificent annotated "Bibliography of the Reference Works and Histories in Medicine and the Allied Sciences" numbering almost 2,000 entries. This bibliography was the outstanding feature of the first edition. It is here revised, augmented (the number of entries has doubled), and rearranged. Formerly the bibliography was arranged primarily by form of publication; in the second edition it is arranged basically by subject, and only secondarily by form. Finally, this book has what might be called an indexer's index, the kind which every librarian admires but finds all too infrequently.

This edition appears as its co-editor, Janet Doe, who edited the first edition, retires following a distinguished career at the New 
York Academy of Medicine Library. It is a monument to her wisdom, her enthusiasm, her organizational skill, and her unflagging zeal for the improvement of medical librarianship. To Miss Doe, to her co-editor, Mary Louise Marshall, and to their talented collaborators, all medical librarians are indebted. This edition is a considerable improvement over its predecessor, and that is high praise indeed.-Lt. Col. Frank $B$. Rogers, Armed Forces Medical Library.

\section{Medical Catalog}

Armed Forces Medical Library Catalog; a Cumulative List of Works Represented by Armed Forces Medical Library Cards, 19501954. Ann Arbor: J. W. Edwards, 1955. Authors: v. 1-3; subjects: v. 4-6. $\$ 64$ a set.

In 1946 the Armed Forces Medical Library established a new cataloging program, and in order to make its cataloging records readily available to as many libraries and individuals as possible it was decided to publish the cards in a variety of ways. To quote M. Ruth MacDonald, Assistant Librarian for Cataloging at the Armed Forces Medical Library:

From October 1946-March 1948, the cards were published by the Library of Congress in a medical series (MED) and reproduced in $A$ Catalog of Books Represented by Library of Congress Printed Cards, Supplement 1942-1947, and in the LC Cumulative Catalog, 1948. From April 1948 to December 1949, the cards were mimeographed and retyped copies were published under the titles Army Medical Library Catalog Cards (April-December 1948) and the Army Medical Library Author Catalog 1949. The former was issued as a supplement to the Cumulative Catalog of Library of Congress Printed Cards and the latter as a supplement to the $L C$ Author Catalog.

This edition of the catalog covers the fiveyear period 1950-1954 and supersedes the annual volumes for 1950-1953 (i.e., the Army Medical Library Catalog 1951, and the Armed Forces Medical Library Catalog, 19521953). The work is divided into two parts, an author catalog and a subject catalog. In both parts the cards are completely reproduced, giving the author entry, his dates, the title, place of publication, publisher, date, pagination, notes, tracings, Armed Forces
Medical Library Classification, and card number.

The 1950 and 1951 volumes included only medical titles; all succeeding volumes have included material of medical interest. This edition not only contains current material, but lists under Part I, Authors, material published before 1801 and American titles through 1820. Additional titles published during this period will be listed in future issues of the catalog.

Part Two, Subjects, is limited by the library's policy of assigning subject headings only to titles published since 1925 , with the following exceptions: (1) important reference and historical materials; (2) biographies and bibliographies; (3) periodicals; (4) congresses; (5) statistical documents; (6) works about institutions, such as hospitals, clinics, etc.

Altogether about 75,000 titles are listed. Because the Armed Forces Medical Library has an acquisition policy which is international in scope and nearly complete in coverage, this catalog becomes an indispensable bibliographical tool for the world's medical literature published in book or pamphlet form. It is essential for active reference and research libraries; all libraries serving medicine and the allied sciences will find it necessary in the performance of their readers services and technical services.-G. J. Clausman, New York University-Bellevue Medical Center Library.

\section{No Ordinary Year}

\section{Annual Report of the Librarian of Congress} for the Fiscal Year Ending June 30, 1954. Washington, D.C.: The Library of Congress, U.S. Government Printing Office, 1955. $178 \mathrm{p}$.

The Report for fiscal 1954 records as leading events the appointment of a new Librarian of Congress and the accessioning of the ten-millionth book. The list of officers begins with a roll-call of distinction: Luther Harris Evans, Librarian (to July 3, 1953), Verner W. Clapp, Acting Librarian (July 4, 1953_September 1, 1954), L. Quincy Mumford, Librarian of Congress and the accessioning of the Librarian Emeritus-all the names since 1899 but Archibald MacLeish. The guard changed, 